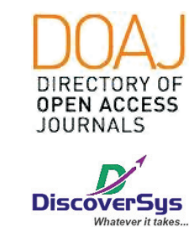

Published by DiscoverSys

\title{
Analisis Corrected Count Increment (CCI) pada penderita post transfusi trombosit apheresis di RSUP Dr. Wahidin Sudirohusodo, Makassar, Indonesia
}

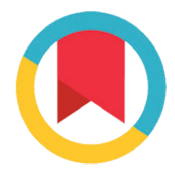

CrossMark

\author{
Lisdiana Amin Asri, ${ }^{1 *}$ Sri Juliani, ${ }^{2}$ Rachmawati Muhiddin ${ }^{2}$
}

\section{ABSTRACT}

Background: Platelet refractoriness is a problem in the implementation of platelet transfusion. It is a lack of increased platelets after platelet transfusion. This study aimed to analyze the increase in platelet counts of patients who received apheresis platelet transfusion by using Corrected Count Increment $(\mathrm{CCl})$ formula at Dr. Wahidin Sudirohusodo General Hospital Makassar.

Methods: This was an observational cross sectional study with 242 thrombocytopenia patients. The success of platelet transfusion was calculated using the $\mathrm{Cl}$ formula with $\mathrm{Cl}$ values after transfusion of $4.5 \times 10^{9} / \mathrm{L}$ at 24 hours post transfusion. Statistical analysis used chi square, t-independent, and spearmen's correlation test, with significant test results if $p$-value was $<0.05$.
Results: An average increase of platelet counts was $28.5 \times 10^{9} / \mathrm{L}$. Successful thrombocyte transfusion was found in 107 subjects (44.2\%) and unsuccessful in 135 subjects (55.8\%). The proportion of successful transfusion was found to be higher in men $(45.5 \%)$ than women (43.2\%), however, it was not significant $(p>0.05)$. There was a significant relationship between young age and successful thrombocyte transfusion $(p<0.001)$. Unsuccessful transfusion rate was high in cases of malignancy, infection, bleeding, and metabolic disease $(p<0.05)$.

Conclusions: There was a significant negative correlation between age and $\mathrm{Cl}$, older age presented lower value of $\mathrm{Cl}$. Characteristics of disease affected the successful of apheresis thrombocyte transfusion.

Keywords: corrected count increment, transfusion, platelet apheresis

Cite This Article: Asri, L.A., Juliani, S., Muhiddin, R. 2019. Analisis Corrected Count Increment (CCI) pada penderita post transfusi trombosit apheresis di RSUP Dr. Wahidin Sudirohusodo, Makassar, Indonesia. Intisari Sains Medis 10(2): 398-402. D0I: 10.15562/ism.v10i2.364

ABSTRAK

Pendahuluan: Platelet refractoriness merupakan salah satu masalah dalam pelaksanaan transfusi trombosit. Platelet refractoriness adalah kurangnya peningkatan trombosit pasca transfusi trombosit. Tujuan dari penelitian ini adalah menganalisa peningkatan jumlah trombosit pasien yang mendapatkan transfusi trombosit apheresis dengan menggunakan formula Corrected Count Increment (CCl) di RSUP Dr. Wahidin Sudirohusodo Makassar.

Metode: Ini merupakan penelitian observasional potong lintang dengan sampel penelitian sebanyak 242 pasien trombositopenia. Keberhasilan transfusi trombosit dihitung dengan menggunakan formula $\mathrm{CCl}$ dengan nilai CCl setelah transfusi $4.5 \times 10^{9} / \mathrm{L}$ pada 24 jam pasca transfusi. Analisis statistik menggunakan uji chi square, uji t-independent, dan uji korelasi spearmen's, dengan hasil uji signifikan jika $\mathrm{p}<0.05$.
Hasil : Peningkatan jumlah trombosit rata-rata $28.5 \times 10^{9} / \mathrm{L}$. Kategori berhasil didapatkan pada 107 subyek (44.2\%) dan tidak berhasil pada 135 subyek (55.8\%). Transfusi trombosit apheresis yang berhasil ditemukan lebih tinggi pada laki-laki (45.5\%) daripada perempuan (43.2\%) namun tidak signifikan ( $p>0.05$ ). Terdapat hubungan antara usia muda dengan keberhasilan transfuse trombosit ( $\mathrm{c} 0.001)$. Angka ketidakberhasilan transfuse trombosit cukup tinggi pada kasus keganasan, infeksi, perdarahan dan penyakit metabolik $(p<0.05)$.

Kesimpulan : Uji korelasi antara umur dengan $\mathrm{CCl}$, ditemukan korelasi negatif yang signifikan, semakin tua umur semakin rendah nilai CCl, serta karakteristik diagnosis penyakit berpengaruh terhadap keberhasilan transfusi apheresis.

*Korespondensi:

Lisdiana Amin Asri; Program

Pendidikan Dokter Spesialis Patologi Klinis, Fakultas Kedokteran Universitas Hasanuddin, RSUP Dr. Wahidin Sudirohusodo, Makassar; diana.aminasri@gmail.com

Diterima: $13-11-2018$

Disetujui: 26-12-2018

Diterbitkan: 01-08-2019
Kata kunci: corrected count increment, transfusi, trombosit apheresis

Cite Pasal Ini: Asri, L.A., Juliani, S., Muhiddin, R. 2019. Analisis Corrected Count Increment (CCI) pada penderita post transfusi trombosit apheresis di RSUP Dr. Wahidin Sudirohusodo, Makassar, Indonesia. Intisari Sains Medis 10(2): 398-402. D0I: 10.15562/ism.v10i2.364

\section{PENDAHULUAN}

Trombosit apheresis adalah salah satu komponen darah untuk transfusi yang diperoleh dengan teknik apheresis. Komponen darah ini didapatkan langsung dari donor tunggal melalui proses 
apheresis trombosit menggunakan peralatan pemisahan sel otomatis. Volume yang diambil dan kandungan apheresis trombosit ekuivalen dengan pooling dari 4-6 kantong tunggal yang setara dengan 4-6 unit konsentrat trombosit. ${ }^{1,2,3}$

Transfusi trombosit diharapkan dapat meningkatkan jumlah trombosit. Keberhasilan transfusi trombosit dinilai dari peningkatan jumlah trombosit setelah transfusi. Efektivitas kenaikan jumlah trombosit setelah transfusi trombosit dapat dipengaruhi oleh berbagai faktor diantaranya adalah sebagai akibat dari perbedaan dosis trombosit, sumber trombosit (apheresis atau trombosit konsentrat), kompatibilitas donor-resepien, dan masa penyimpanan trombosit serta adanya sifat refrakter terhadap transfusi trombosit (platelet refractoriness). Masing-masing karakteristik ini dapat mempengaruhi peningkatan jumlah trombosit pasca transfusi. ${ }^{4}$

Platelet refractoriness merupakan salah satu masalah dalam pelaksanaan transfusi trombosit. Platelet refractoriness didefinisikan sebagai kurangnya peningkatan trombosit pasca transfusi trombosit (Murphy, 2014). Platelet refractoriness akan mengakibatkan pemberian transfusi trombosit berulang kepada pasien yang berimbas pada peningkatan permintaan penyediaan transfusi trombosit, dan pada akhirnya akan meningkatkan biaya perawatan kesehatan. Untuk menghindari hal tersebut diperlukan suatu metode yang sama untuk menilai efektivitas peningkatan jumlah trombosit setelah transfusi trombosit. ${ }^{5}$

Beberapa formula yang dapat digunakan untuk menilai tingkat keberhasilan transfusi trombosit, diantaranya adalah Post-Transfusion Platelet Increment (PI), Percentage Platelet Recovery (PPR), dan Corrected Count Increment (CCI). PI adalah perhitungan yang paling sederhana dan paling sering digunakan dalam praktek rutin dengan cara menghitung selisih jumlah trombosit sesudah transfusi dan sebelum transfusi trombosit. PPR adalah selisih kenaikan trombosit $\left(\mathrm{PI}\left(\mathrm{mm}^{3}\right)\right)$ tiap satuan volume darah (liter) dalam satu dosis pemberian transfusi trombosit $\left(\mathrm{PD}\left(\mathrm{mm}^{3}\right)\right)$. CCI adalah selisih kenaikan jumlah trombosit $\left(\mathrm{PI}\left(\mathrm{mm}^{3}\right)\right)$ setiap satuan luas permukaan tubuh (Body Surface Areal BSA $\left(\mathrm{mm}^{2}\right)$ ) dalam satu dosis pemberian transfusi trombosit $\left(\mathrm{PD}\left(\mathrm{mm}^{3}\right)\right)$. Transfusi trombosit apheresis dikatakan berhasil bila nilai CCI adalah $7.5 \mathrm{x}$ $10^{9} / \mathrm{L}$ pada 1 jam pasca transfusi dan $4.5 \times 10^{9} / \mathrm{L}$ pada 24 jam pasca transfusi..$^{2,5,6}$

Penelitian yang dilakukan oleh Stanworth et al. menyatakan bahwa perhitungan tingkat keberhasilan transfusi trombosit dengan menggunakan formula CCI memang kurang praktis karena memerlukan data jumlah trombosit yang ditransfusikan serta data berat badan dan tinggi badan.
Namun beberapa center banyak menggunakannya karena dianggap lebih akurat dalam menentukan tingkat keberhasilan transfusi trombosit. ${ }^{6}$ Holbro et al. juga menyatakan bahwa CCI adalah penanda yang paling banyak digunakan untuk mengukur keefektifan transfusi trombosit, karena hasil perhitungan CCI tidak dipengaruhi oleh klinis pasien yang mengalami perdarahan. ${ }^{5}$

Berdasarkan uraian diatas, tujuan dari penelitian ini adalah menganalisa peningkatan jumlah trombosit pasien yang mendapatkan transfusi trombosit apheresis dengan menggunakan formula corrected count increment.

\section{METODE}

Penelitian ini merupakan penelitian observasional potong lintang yang dilakukan di Laboratorium Patologi Klinik RSUP. Dr. Wahidin Sudirohusodo Makassar pada bulan Agustus hingga September 2018. Data pada penelitian ini adalah data sekunder rekam medik pasien periode Januari hingga Desember 2017 di RS dr. Wahidin Sudirohusodo. Kriteria inklusi pada penelitian ini adalah semua populasi terjangkau dengan gejala klinis trombositopenia dan mendapatkan transfusi trombosit apheresis, memiliki data pemeriksaan darah rutin sebelum dan sesudah transfusi serta memiliki data berat badan dan tinggi badan.

Data dihitung menggunakan formula CCI. Transfusi trombosit apheresis dikatakan berhasil bila nilai CCI setelah transfusi $4.5 \times 10^{9} / \mathrm{L}$ pada 24 jam pasca transfusi. Selanjutnya data dianalisis dengan menggunakan SPSS. Analisis statistik yang dilakukan adalah uji statistik uji chi square, t-independen, dan uji korelasi spearman's. Hasil uji dikatakan signifikan apabila nilai $\mathrm{p}<0.05$.

Persetujuan kelayakan etik diperoleh dari Komisi Etik Penelitian Kesehatan Fakultas Kedokteran Universitas Hasanuddin Rumah Sakit Umum Pusat Dr. Wahidin Sudirohusodo Makassar.

\section{HASIL}

Terdapat 242 subyek pasca transfusi trombosit apheresis yang memenuhi kriteria inklusi. Umur subyek antara $2-79$ tahun dengan rerata 30.3 tahun. Hasil perhitungan CCI menunjukkan nilai yang sangat bervariasi yaitu antara $-2.95-486.95$ dengan rerata 28.5 dan median 3.31. Berdasarkan keberhasilan transfusi, 107 subyek (44.2\%) masuk dalam kategori berhasil dan 135 subyek (55.8\%) masuk dalam kategori tidak berhasil. Karakteristik subyek menunjukkan sebagian besar adalah perempuan (54,5\%), berumur antara $10-29$ tahun (28.5\%), dan penyakit terbanyak adalah keganasan (87.2\%). Data lengkap dapat dilihat pada Tabel 1. 
Tabel 1 Karakteristik umum sampel penelitian $(\mathbf{n}=\mathbf{2 4 2})$

\begin{tabular}{lc}
\hline Variabel & $\mathbf{N}(\%)$ \\
\hline Jenis kelamin & $110(45,5 \%)$ \\
Laki - laki & $132(54,5 \%)$ \\
Perempuan & \\
Umur* & $62(25,6 \%)$ \\
$\leq 10$ tahun & $39(16,1 \%)$ \\
$>10-\leq 18$ tahun & $21(8,7 \%)$ \\
$>18-\leq 29$ tahun & $57(23,6 \%)$ \\
$>29-\leq 49$ tahun & $63(26,0 \%)$ \\
$>49$ tahun & \\
Diagnosis penyakit & $11(4,54 \%)$ \\
Infeksi & $211(87,2 \%)$ \\
Keganasan & $6(2,48 \%)$ \\
Penyakit metabolik & $14(5,79 \%)$ \\
Perdarahan & \\
Keberhasilan transfusi (CCI) & $107(44,2 \%)$ \\
Berhasil & $135(55,8 \%)$ \\
Tidak berhasil & \\
\hline
\end{tabular}

*Kelompok umur berdasarkan kuartil

Tabel 2 Perbandingan jenis kelamin dan CCI

\begin{tabular}{lcccc}
\hline & \multicolumn{2}{c}{ CCI } & & \multirow{2}{*}{ Jenis kelamin } \\
\cline { 2 - 3 } Laki - laki & Berhasil & Tidak berhasil & & Potal \\
\hline Perempuan & $50(45.5 \%)$ & $60(54.5 \%)$ & $110(100 \%)$ & \\
Total & $57(43.2 \%)$ & $75(56.8 \%)$ & $132(100 \%)$ & 0.723 \\
\hline & $107(44.2 \%)$ & $135(55.8 \%)$ & $242(100 \%)$ & \\
\hline
\end{tabular}

Tabel 3 Perbandingan umur dan $\mathrm{CCl}$

\begin{tabular}{lccc}
\hline CCI & n & Rerata \pm SD & P \\
\hline Berhasil & 107 & $17.04 \pm 17.99$ & \\
Tidak berhasil & 135 & $40.82 \pm 18.22$ & $<0.001$ \\
\hline
\end{tabular}

Tabel 4 Perbandingan kelompok umur dengan $\mathrm{CCl}$

\begin{tabular}{|c|c|c|c|c|}
\hline \multirow[b]{2}{*}{ Umur } & \multicolumn{2}{|c|}{$\mathrm{CCl}$} & \multirow[b]{2}{*}{ Total } & \multirow[b]{2}{*}{$\mathbf{P}$} \\
\hline & Berhasil & Tidak berhasil & & \\
\hline$\leq 10$ tahun & $59(95,2 \%)$ & $3(4,8 \%)$ & $62(100 \%)$ & \multirow{6}{*}{$<0.001$} \\
\hline$>10-\leq 18$ tahun & $21(53,8 \%)$ & $18(46,2 \%)$ & $39(100 \%)$ & \\
\hline$>18-\leq 29$ tahun & $7(33,3 \%)$ & $14(66,7 \%)$ & $21(100 \%)$ & \\
\hline$>29-\leq 49$ tahun & $6(10,5 \%)$ & $51(89,5 \%)$ & $57(100 \%)$ & \\
\hline$>49$ tahun & $14(22,2 \%)$ & $49(77,8 \%)$ & $63(100 \%)$ & \\
\hline Total & $107(44,2 \%)$ & $135(55,8 \%)$ & $242(100 \%)$ & \\
\hline
\end{tabular}

Transfusi trombosit apheresis yang berhasil ditemukan sedikit lebih tinggi pada laki-laki (45.5\%) dibandingkan pada perempuan (43.2\%), namun hasil uji statistik menunjukkan bahwa perbedaan tersebut tidak signifikan $(\mathrm{p}>0.05)$. (Tabel 2)

Pada Tabel 3 dapat dilihat bahwa pada transfusi trombosit apheresis yang berhasil, rerata umur lebih muda dibandingkan transfusi yang tidak berhasil.

Pada Tabel 4 dapat dilihat bahwa terdapat hubungan antara usia muda dengan keberhasilan transfusi trombosit apheresis $(\mathrm{p}<0.001)$. Transfusi trombosit apheresis yang berhasil tertinggi pada umur $\leq 10$ tahun (95.2\%) dan menurun pada usia yang lebih tua.

Berdasarkan uji korelasi antara umur dengan keberhasilan transfusi trombosit apheresis, ditemukan adanya korelasi negatif yang signifikan diantara keduanya, dimana semakin tua umur semakin rendah nilai CCI $(r=-0.635 ; \mathrm{p}<0.001)$. Hasil ini menunjukkan bahwa semakin tua umur semakin kecil kemungkinan keberhasilan transfusi trombosit apheresis. Pada Gambar 1 terlihat sebaran subyek dengan transfusi yang berhasil sebagian besar berumur $<20$ tahun, walaupun ada juga sebagian kecil yang berumur diatas 40 tahun tetapi dianggap nilai ekstrim.

Pada Tabel 5 dapat dilihat bahwa diagnosis pasien berhubungan dengan keberhasilan CCI $(\mathrm{p}<0.05)$. Ketidakberhasilan transfusi trombosit apheresis berhubungan dengan infeksi, keganasan, penyakit metabolik, dan perdarahan.

\section{PEMBAHASAN}

Pada penelitian ini ditemukan proporsi keberhasilan transfusi trombosit yang dihitung dengan formula CCI ditemukan sedikit lebih tinggi pada laki-laki dibandingkan pada perempuan, namun hasil uji statistik menunjukkan bahwa perbedaan tersebut tidak signifikan $(p>0.05)$. Variasi susunan anatomis dan kondisi fisiologi pada pria dan wanita yang berbeda akan memberikan hasil yang berbeda pula, dan laju metabolisme pada wanita diketahui sedikit lebih rendah. ${ }^{8}$

Transfusi trombosit apheresis yang berhasil tertinggi pada umur $<10$ tahun dan menurun dengan bertambahnya usia. Terdapat korelasi antara umur dengan keberhasilan transfusi trombosit, ditemukan adanya korelasi negatif yang signifikan diantara keduanya, semakin tua umur semakin rendah nilai CCI (r: - 0.635; $\mathrm{p}<0.001)$. Hasil ini menunjukkan bahwa semakin tua umur semakin kecil kemungkinan keberhasilan CCI. Kemampuan metabolisme dalam tubuh akan mengalami penurunan seiring dengan bertambahnya usia, sehingga usia akan sangat mempengaruhi proses trombopoiesis. ${ }^{7}$

Yang Xu et al. ${ }^{9}$ dalam penelitiannya menyatakan bahwa pemberian Human Growth Hormone (hGH) 
Tabel 5 Hubungan berbagai jenis diagnosis dengan $\mathrm{CCI}$

\begin{tabular}{lcccc}
\hline & \multicolumn{2}{c}{ CCI N(\%) } & & \multirow{2}{*}{ Diagnosis } \\
\cline { 2 - 3 } Infeksi & Berhasil & Tidak berhasil & Total & P \\
Keganasan & $3(27.3 \%)$ & $8(72.7 \%)$ & $11(100 \%)$ & \\
Penyakit metabolik & $102(48.3 \%)$ & $109(51.7 \%)$ & $211(100 \%)$ & \\
Perdarahan & $0(0.0 \%)$ & $6(100 \%)$ & $6(100 \%)$ & 0.014 \\
Total & $2(21.4 \%)$ & $12(78.6 \%)$ & $14(100 \%)$ & \\
\hline
\end{tabular}

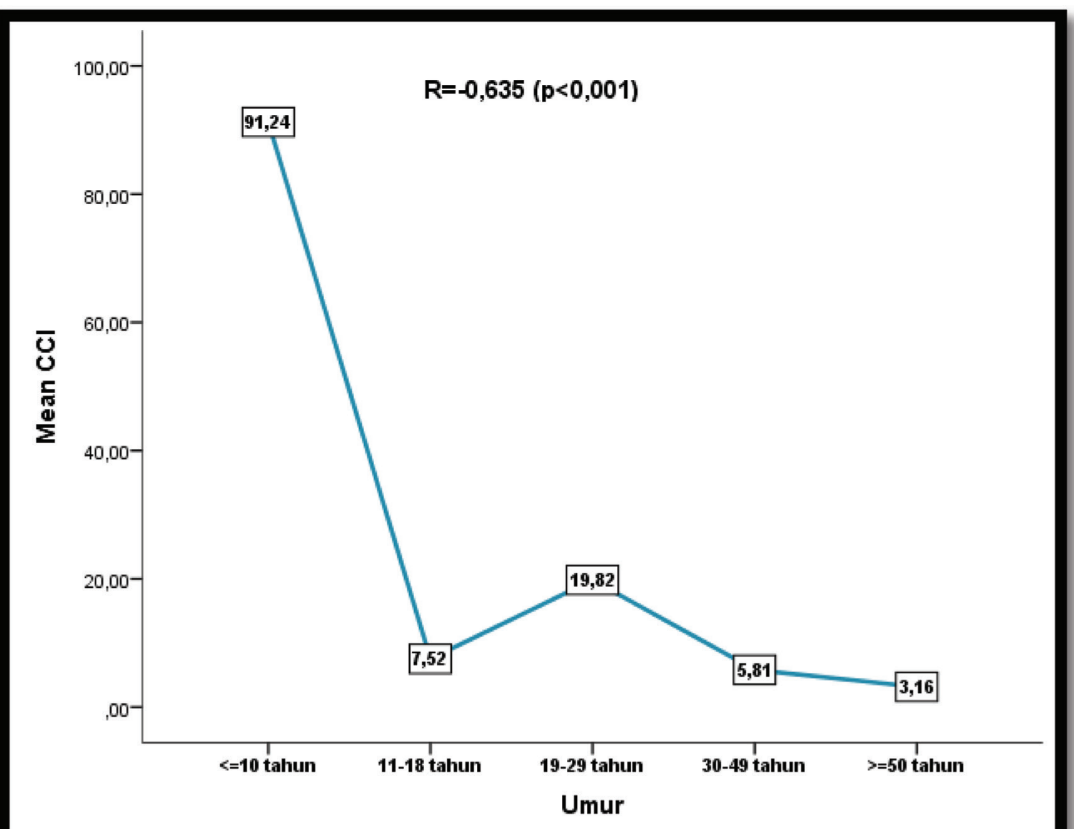

Spearman's Correlation test

Gambar 1 Korelasi umur dengan CCI

akan meningkatkan efek tandem dimer dari Peptida Mimetic Thrombopoietin (dTMP) dalam proses trombopoiesis dan mengakibatkan akselerasi serta peningkatan produksi trombosit yang signifikan. Hal ini menunjukkan bahwa hGH dapat memberikan efek yang saling melengkapi dan sinergis dengan ligan c-Mpl pada trombopoiesis. ${ }^{9}$ Sejalan dengan penelitian ini, kepustakaan lain menyatakan bahwa konsentrasi hGH plasma rata-rata akan mengalami penurunan seiring dengan bertambahnya usia. Pada usia 5-20 tahun, konsentrasi hGH plasma rata-rata $6 \mathrm{ng} / \mathrm{ml}$, usia 20-40 tahun sekitar $3 \mathrm{ng} / \mathrm{ml}$ dan pada usia 40-70 tahun kira-kira $1.6 \mathrm{ng} / \mathrm{ml}$. Sehingga sangat mungkin bahwa pertambahan usia akan mempengaruhi trombopoiesis. ${ }^{8}$

Komplikasi utama dalam penatalaksanaan pasien trombositopenia adalah platelet refractoriness. Ini terjadi karena penyebab imun atau non-imun. Penyebab refrakter non-imun termasuk demam, infeksi, obat-obatan, splenomegali dan koagulasi intravaskular diseminata. Pemeriksaan riwayat pasien yang rinci dan temuan pemeriksaan fisik membantu untuk menjelaskan penyebab dan menentukan tujuan serta urgensi pengobatan. Pada pasien yang memiliki respon buruk terhadap transfusi trombosit, pengukuran jumlah trombosit pasca transfusi sekitar 24 jam setelah transfusi trombosit dapat membantu membedakan antara penyebab imun dan non-imun. ${ }^{2}$ Sejalan dengan penelitian ini ditemukan bahwa dari 242 pasien yang ditransfusi apheresis, ditemukan 135 pasien yang mengalami platelet refractoriness dengan nilai $\mathrm{CCI}<4.3 \times 10^{9} / \mathrm{L}$.

Hasil penelitian kami juga menunjukkan bahwa dari 242 pasien, didapatkan angka ketidakberhasilan transfusi trombosit apheresis yang tinggi pada kasus keganasan (51.7\%), infeksi (72.7\%), perdarahan $(78.6 \%)$ dan penyakit metabolik (100\%) dengan perbedaan yang signifikan. Hoffbrand et al. mengemukakan bahwa penyebab trombositopenia pada kasus keganasan sebagai akibat dari kegagalan produksi trombosit sehingga konsumsi trombosit juga akan meningkat. ${ }^{10}$ Kiefel et al. dalam penelitiannya menemukan bahwa dari 252 pasien keganasan, ditemukan 113 (44.8\%) pasien memiliki platelet reactive antibodies, 108 pasien dengan antibodi human leukocyte antigen (HLA) dan antibodi human platelet antigen (HPA) pada 20 pasien. Alcotra et al. dalam penelitiannya juga menemukan adanya antibodi HLA pada pasien-pasien keganasan hematologi yang secara signifikan terkait dengan platelet refractoriness. ${ }^{11}$

Fabris et al. dalam penelitiannya telah mempelajari bahwa dari 25 pasien yang mendapatkan transfusi trombosit dalam jumlah yang banyak dan berulang, 67\% ditemukan antibodi HLA dan mengalami platelet refractoriness. Hal ini memiliki keterkaitan dengan kasus perdarahan pasca operasi yang membutuhkan apheresis dalam jumlah yang banyak untuk tindakan profilaksis terjadinya perdarahan akut yang mengancam nyawa. Demikian pula pada kasus penyakit metabolik seperti diabetes mellitus disertai penyakit ginjal kronik, trombositopenia dipicu oleh pemakaian heparin (heparin-induced thrombocytopenia). Sedangkan trombositopenia untuk kasus infeksi, kemungkinan karena depresi megakariosit oleh infeksi virus dan bakteri. Penyakit kronis akan berakhir pada trombositopenia yang akan mengakibatkan pemberian transfusi berulang sehingga memunculkan adanya antibodi HLA dan menjadi salah satu faktor penyebab platelet refractoriness. ${ }^{10,11}$

\section{SIMPULAN}

Tingkat keberhasilan transfusi trombosit paling tinggi pada kelompok usia $<10$ tahun (95.2\%) dan menurun pada usia yang lebih tua. Ketidakberhasilan transfusi trombosit apheresis 
terjadi pada penyakit keganasan, perdarahan, infeksi dan penyakit metabolik.

\section{ETIKA PENELITIAN}

Penelitian ini telah mendapat persetujuan etik oleh komisi etik Fakultas Kedokteran Universitas Hasanuddin, RSUP Dr. Wahidin Sudirohusodo, Makassar, Indonesia.

\section{KONFLIK KEPENTINGAN}

Tidak terdapat konflik kepentingan dalam penyusunan artikel penelitian ini.

\section{PENDANAAN}

Studi ini didanai langsung oleh penulis tanpat keterlibatan berbagai jenis sponsor, grant, atau jenis sumber pendanaan lainnya.

\section{KONTRIBUSI PENULIS}

Seluruh penulis memiliki kontribusi yang sama dalam penyusunan laporan akhir hasil penelitian ini baik dalma hal pengajuan usulan penelitian, pengambilan sampel penelitian, analisis data penelitian, hingga laporan akhir penelitian.

\section{DAFTAR PUSTAKA}

1. Dalimoenthe ZN. Persiapan Transfusi. Dasar-dasar Transfusi Darah. Edisi Kedua. Bandung: Divisi Hematologi Klinik. Departemen/SMF Patologi Klinik Fakultas Kedokteran Universitas Padjadjaran; 2014: 84
2. Petraszko T, Zeller M. Platelet Transfusion, Alloimmunization and Management of Platelet Refractoriness. Clinical Guide to Transfusion. Chapter 18. 2018; 1-18. Available from: https://professionaleducation. blood.ca/en/transfusion/clinicalguide/platelettransfusion-alloimmunization-and-management-platelet [Accessed 20 $0^{\text {th }}$ June 2018].

3. Anonim. Peraturan Menteri Kesehatan Republik Indonesia Nomor 91 Tahun 2015 Tentang Standar Pelayanan Transfusi Darah. Jakarta; 2015; 109 - 111.

4. Triulzi DJ, Assmann SF, Strauss RG, Ness PM, Hess JR, Kaufmann RM et al. The impact of platelet transfusion characteristics on posttransfusion platelet increments and clinical bleeding in patients with hypoproliferative thrombocytopenia. Blood. 2012; 119(23): 5553 - 62 .

5. Stanworth SJ, Navarrete C, Estcourt L, Marsh J. Platelet refractoriness - practical approaches and ongoing dilemmas in patient management. Br J Haematol. 2015; 171(3): $297-305$.

6. Holbro A, Infanti L, Sigle J, Buser A. Platelet transfusion: basic aspects. Swiss Med Wkly. 2013; 143: w13885.

7. Guyton. Pituitary Hormones and Their Control by the Hypopthalamus. In: Guyton and Hall Textbook of Medical Physiology. $13^{\text {th }}$ Edition. London: Elsevier; 2016: 847-57.

8. Barret KE, Barman SM, Baitano S. Ganong's Review of Medical Physiology. 25 $5^{\text {th }}$ edition. USA: McGraw-Hill Education; 2016.

9. Xu Y, Wang S, Shen M, Zhang Z, Chen S, Chen F et al. hGH promotes megakaryocyte differentiation and exerts a complementary effect with c-Mpl ligands on thrombopoiesis. Blood. 2014; 123(14): 2250 - 60.

10. Hoffbrand AV, Moss PAH. Platelets, Blood Coagulation and Haemostasis. Australia: Blackwell Publishing; 2013; $264-277$.

11. Shastry S, Chaudhary R. Clinical factors influencing corrected count increment. Transfus Apher Sci. 2012; 47(3): $327-30$.

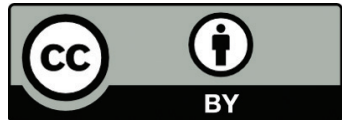

This work is licensed under a Creative Commons Attribution 